\title{
Anti-Cancer Effects of Pristimerin and the Mechanisms: A Critical Review
}

\author{
Jia-jun Li't, Yan-yan Yan ${ }^{2,3 t}$, Hong-mei Sun ${ }^{4 \dagger}$, Yun Liu', Chao-yue Su ${ }^{1}$, Hu-biao Chen ${ }^{3 *}$ \\ and Jian-ye Zhang ${ }^{1 *}$ \\ ' Guangdong Provincial Key Laboratory of Molecular Target \& Clinical Pharmacology, School of Pharmaceutical Sciences and \\ the Fifth Affiliated Hospital, Guangzhou Medical University, Guangzhou, China, ${ }^{2}$ Institute of Respiratory and Occupational \\ Diseases, Collaborative Innovation Center for Cancer, Medical College, Shanxi Datong University, Datong, China, ${ }^{3}$ School of \\ Chinese Medicine, Hong Kong Baptist University, Hong Kong, China, ${ }^{4}$ Infinitus (China) Company Ltd., Jiangmen, China
}

OPEN ACCESS

Edited by:

Syed Nasir Abbas Bukhari, Al Jouf University,

Saudi Arabia

Reviewed by:

Li Ye,

Fudan University, China

Waqas Ahmad,

University of Science Malaysia, Malaysia

*Correspondence: Jian-ye Zhang jianyez@gzhmu.edu.cn Hubiao Chen

hbchen@hkbu.edu.hk

tThese authors have contributed equally to this work.

Specialty section:

This article was submitted to Experimental Pharmacology and Drug Discovery, a section of the journal Frontiers in Pharmacology

Received: 26 January 2019 Accepted: 11 June 2019

Published: 12 July 2019

Citation:

Li J-j, Yan Y-y, Sun H-m, Liu Y, Su C-y, Chen $\mathrm{H}-\mathrm{b}$ and Zhang $\mathrm{J}-\mathrm{y}$ (2019) Anti-Cancer Effects of Pristimerin and the Mechanisms: A Critical Review.

Front. Pharmacol. 10:746. doi: 10.3389/fphar.2019.00746
As a quinonemethide triterpenoid extracted from species of the Celastraceae and Hippocrateaceae, pristimerin has been shown potent anti-cancer effects. Specifically, it was found that pristimerin can affect many tumor-related processes, such as apoptosis, autophagy, migration and invasion, vasculogenesis, and drug resistance. Various molecular targets or signaling pathways are also involved, such as cyclins, reactive oxygen species (ROS), microRNA, nuclear factor kappa B (NF-kB), mitogen-activated protein kinase (MAPK), and PI3K/AKT/mammalian target of rapamycin (mTOR) pathways. In this review, we will focus on the research about pristimerin-induced anti-cancer activities to achieve a deeper understanding of the targets and mechanisms, which offer evidences suggesting that pristimerin can be a potent anti-cancer drug.

Keywords: pristimerin, anti-cancer, mechanism, molecular target, pharmaceutical effect, apoptosis, autophagy

\section{INTRODUCTION}

In recent years, natural compound has received more and more attention for use in treating human diseases and conditions, due to their long history of use and various pharmacological therapeutic effects (Tao et al., 2015; Zhang et al., 2015; Peng et al., 2016; Zhang et al., 2016; Lin et al., 2017), especially their relative safety (fewer and less severe side effects) than chemical drugs. Naturally occurring triterpenoid can be used as anti-cancer, anti-inflammatory, antimalarial, and insecticidal agent (Deeb et al., 2012; Larsen et al., 2012; Kim et al., 2013; Deeb et al., 2014a). It has been proven that some natural or synthetic triterpenoids have promising clinical potential, exhibiting both therapeutic and chemopreventive activities for cancer (Salminen et al., 2008; Alessia et al., 2009; Ke et al., 2016). Pristimerin (20a-3-hydroxy-2-oxo-24-nor-friedela1-10,3,5,7-tetraen-carboxylic acid-29-methylester, molecular formula: $\mathrm{C}_{30} \mathrm{H}_{40} \mathrm{O}_{4}$ ) (Figure 1), a methyl ester of celastrol, is a quinonemethide triterpenoid which has been extracted from a variety of species of the Celastraceae and Hippocrateaceae families, such as Hippocratea excels (Mena-Rejon et al., 2007), Maytenus heterophylla (Murayama et al., 2007), and Celastrus aculeatus Merr. (Tang et al., 2014). Pristimerin was first isolated in 1951 from Pristimerae indica and $P$. grahami and was first identified in 1954 to confirm its molecular structure (Kulkarni and Shah, 1954). Pristimerin has displayed different pharmacological effects, such as anti-cancer, antioxidant, anti-inflammatory, anti-bacterial, anti-malarial, and insecticidal activities (Figueiredo 


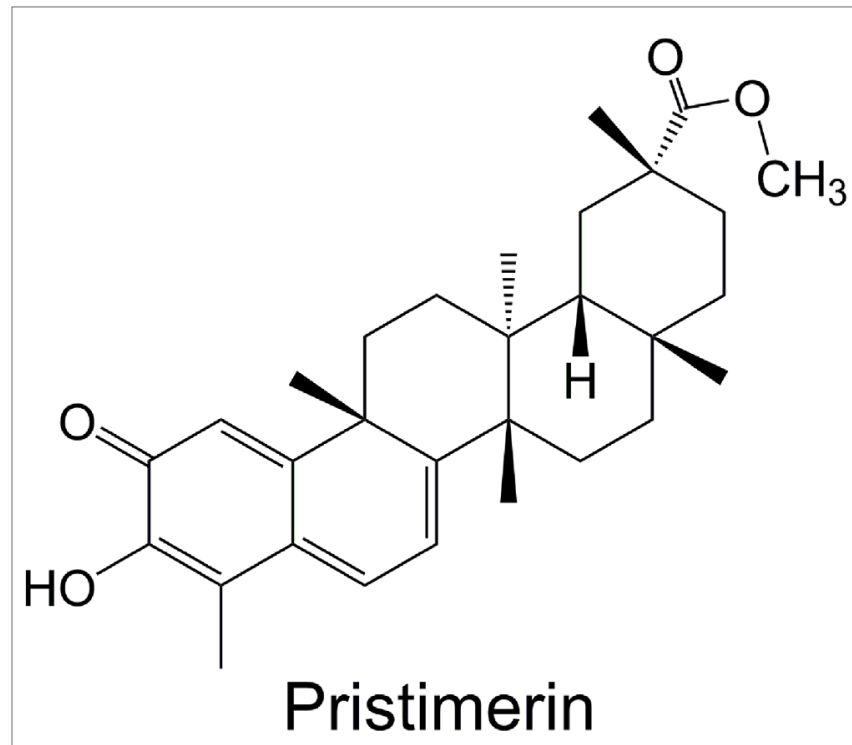

FIGURE 1 | Chemical structure of pristimerin.

and Sequin, 1998; Avilla et al., 2000; Haroldo Jeller et al., 2004; Lopez et al., 2011; Kim et al., 2013; Wu et al., 2019). As such, it is being developed as a potential anti-cancer drug (Yousef et al., 2017). Here, we present and discuss current research findings with regard to pristimerin emphasis on the anti-cancer effect.

\section{PRISTIMERIN: BROAD-SPECTRUM ANTI-CANCER EFFECT}

Cancer is a complicated disease, which starts with a normal change through the activation of proto-oncogenes or the suppression of tumor suppressor genes (Elmore, 2007). These alterations result in diversed and interactive changes at the level of cellular processes which are involved in the regulation of proliferation, differentiation, apoptosis, migration, and tissue homeostasis. Finally, biological properties for cancer cells are acquired, including infinite proliferation potential, independent exogenous growth factors, and resistance to death signals (Brattain et al., 1994; Dent and Aranda-Anzaldo, 2019; Petho et al., 2019; Shen et al., 2019).

Pristimerin exerts its effects influencing a series of biological properties of cancer cells. Recent studies on a wide range of cancer cell lines of different origins, such as oral cancer (Wu et al., 2019), colorectal cancer (Yousef et al., 2018), glioma (Yan et al., 2013), leukemia (Lu et al., 2010), breast cancer (Xie et al., 2016), lung cancer (Zhang et al., 2019), and prostate cancer (Liu et al., 2013), and also in cancer stem cells (Cevatemre et al., 2018). These results have proved that pristimerin possesses strong anti-proliferative activities with involvement of mitochondrial apoptosis, autophagy, and inhibition of nuclear factor kappa B $(\mathrm{NF}-\kappa \mathrm{B})$, Akt (protein kinase $\mathrm{B}, \mathrm{PKB})$ and mitogen-activated protein kinase (MAPK) (Guo et al., 2013; Liu et al., 2013; Yan et al., 2013; Gao et al., 2014; Deeb et al., 2015).
In view of the potent anti-cancer effect in a broad spectrum (cancer cell lines and molecular targets), it possesses a great potential for pristimerin to develop as a multiple-target anticancer drug.

\section{PRISTIMERIN: ANTI-CANCER ACTIVITIES}

\section{Growth Inhibition}

Pristimerin induces a potent effect of growth inhibition within wide range types of human tumors; the cytotoxicity of pristimerin in different cancer cell lines is summarized in Table $\mathbf{1}$.

\section{Apoptosis Induction}

Apoptosis is a kind of programmed cell death, whose activation is regulated by a series of genes, in the purpose of eliminating redundant, damaged, even infected cells to maintain homeostasis (Ke et al., 2016). Anti-cancer agents killing tumor cells by the induction of apoptosis is generally studied (Wu et al., 2017; Xiao et al., 2018; Qi et al., 2019). Two main subtypes of apoptosis have been divided into the intrinsic mitochondrial pathway and the extrinsic death receptor pathway (Elmore, 2007).

In the mitochondrial pathway, Bcl-2 family members converge on mitochondria (Kale et al., 2018), regulating release of various mitochondrial components to form the apoptosome (Dorstyn et al., 2018), such as cytochrome $c$ associated with Apaf-1 and procaspase-9 (Estaquier et al., 2012). In the death receptor pathway, stimulation of death receptors, including Fas and tumor necrosis factor (TNF) receptor-1, results in the assembly of death-inducing signaling complex, containing the adapter protein (Gupta, 2001), Fasassociated death domain, and initiator caspases, such as caspase-8 (Pecina-Slaus, 2009).

Pristimerin-induced apoptotic effects were mainly due to mitochondrial dysfunction, activation of both extrinsic and intrinsic caspases, and cleavage of poly ADP-ribose polymerase (PARP). It has been reported that pristimerin can induce caspase-dependent apoptosis in human glioma cancer cells (Yan et al., 2013), pancreatic cancer cells (Deeb et al., 2014b), and hepatoma cancer cells (Gao et al., 2014). Pristimerin-induced inhibition of Bcl-2 (as well as Bcl-2 mRNA) is sufficient to promote mitochondrial permeability transition and release of cytochrome $c$ mediated by Bax and Bak without the inhibition of Bcl-xL in pancreatic cancer cells (Deeb et al., 2014b). On the other hand, caspase inhibitor failed to antagonize the effects of pristimerin, indicating that the lethal effect of pristimerin may not be caspase-dependent in human glioma U251 and U87 cells (Zhao et al., 2016).

The apoptotic effect of pristimerin is related to $\mathrm{Bcl}-2$, and it mediates down-regulation of $\mathrm{Bcl}-2$ through reactive oxygen species (ROS)-dependent ubiquitin-proteasomal degradation pathway in human prostate cancer LNCaP and PC-3 cells (Liu et al., 2013). ROS-induced apoptosis by pritimerin was also reported in hepatocellular carcinoma HepG2 cells, involving EGFR and Akt proteins (Guo et al., 2013). In colorectal carcinoma cells, 
TABLE 1 | The cytotoxicity dosage of pristimerin in different cancer cell lines.

\begin{tabular}{|c|c|c|c|}
\hline Cancer type & Time & Toxic dosage ( $\left(\mathrm{C}_{50}\right.$ value or inhibition rate) & References \\
\hline Prostate cancer & $72 \mathrm{~h}$ & $\begin{array}{l}1.25 \mu \mathrm{M} \text { caused } 55 \% \text { LNCaP cell death } \\
1.25 \mu \mathrm{M} \text { caused } 47 \% \text { PC-3 cell death }\end{array}$ & (Liu et al., 2013) \\
\hline Breast cancer & $24 \mathrm{~h}$ & $2.40 \mu \mathrm{M} \mathrm{IC} \mathrm{C}_{50}$ against SKBR3 & (Lee et al., 2013) \\
\hline Colorectal cancer & $\begin{array}{l}72 \mathrm{~h} \\
48 \mathrm{~h}\end{array}$ & $\begin{array}{l}1.11 \mu \mathrm{M} \mathrm{IC} \mathrm{I}_{50} \text { against HCT-116 } \\
1.22 \mu \mathrm{M} \mathrm{IC} \mathrm{I}_{50} \text { against HCT-116 } \\
1.04 \mu \mathrm{M} \mathrm{IC} \mathrm{C}_{50} \text { against SW-620 } \\
0.84 \mu \mathrm{M} \mathrm{IC} \mathrm{C}_{50} \text { against COLO-205 }\end{array}$ & $\begin{array}{l}\text { (Yousef et al., 2018) } \\
\text { (Yousef et al., 2016a) }\end{array}$ \\
\hline Hepatocellular carcinoma & $72 \mathrm{~h}$ & $\begin{array}{l}1.44 \mu \mathrm{M} \mathrm{IC} \mathrm{C}_{50} \text { against HepG2 } \\
1.70 \mu \mathrm{M} \mathrm{IC} \mathrm{C}_{50} \mu \mathrm{M} \text { against HepG2 } \\
0.68 \mu \mathrm{M} \mathrm{IC}_{50} \mu \mathrm{M} \text { against Huh7 } \\
0.85 \mu \mathrm{M} \mathrm{IC} \mathrm{C}_{50} \mu \mathrm{M} \text { against Hep3B }\end{array}$ & $\begin{array}{l}\text { (Guo et al., 2013) } \\
\text { (Wei et al., 2014) }\end{array}$ \\
\hline Pancreatic cancer & $\begin{array}{l}24 \mathrm{~h} \\
48 \mathrm{~h} \\
72 \mathrm{~h}\end{array}$ & $\begin{array}{l}0.66 \mu \mathrm{M}, 0.97 \mu \mathrm{M}, 0.13 \mu \mathrm{M}, \mathrm{IC}_{50} \text { against BxPC-3, PANC-1, and AsPC-1, respectively } \\
0.28 \mu \mathrm{M}, 0.34 \mu \mathrm{M} \text {, and } 0.38 \mu \mathrm{M} \mathrm{IC}_{50} \text { against BxPC-3, PANC-1, and AsPC-1, respectively } \\
0.19 \mu \mathrm{M}, 0.26 \mu \mathrm{M} \text { and } 0.30 \mu \mathrm{M} \mathrm{IC}_{50} \text { against BxPC-3, PANC-1, and AsPC-1, respectively }\end{array}$ & (Wang et al., 2012) \\
\hline Glioma & $6 \mathrm{~h}$ & $\begin{array}{l}4.5 \mu \mathrm{M} \mathrm{IC}{ }_{50} \text { against } \mathrm{U} 251 \\
5.0 \mu \mathrm{M} \mathrm{IC} \\
50 \text { against } U 87\end{array}$ & (Zhao et al., 2016) \\
\hline Leukemia & $72 \mathrm{~h}$ & $\begin{array}{l}0.61 \mu \mathrm{M} I \mathrm{C}_{50} \text { against } \mathrm{HL}-60 \\
1.49 \mu \mathrm{M} \mathrm{IC}_{50} \text { against } \mathrm{K} 562\end{array}$ & (Costa et al., 2008) \\
\hline & $72 \mathrm{~h}$ & $\begin{array}{l}199 \mathrm{nM} \mathrm{IC}_{50} \text { against KBM5 } \\
135 \mathrm{nM} \mathrm{IC}_{50} \text { against KBM5-T315I } \\
450 \mathrm{nM} \mathrm{IC}_{50} \text { against K562 }\end{array}$ & (Lu et al., 2010) \\
\hline Ovarian carcinoma & $72 \mathrm{~h}$ & $\begin{array}{l}1.25 \mu \mathrm{M} \text { caused } 44 \% \text { OVCAR-5 cell death } \\
1.25 \mu \mathrm{M} \text { caused } 28 \% \text { MDAH- } 2774 \text { cell death } \\
2.5 \mu \mathrm{M} \text { caused } 36 \% \text { SK-OV-3 cell death } \\
2.5 \mu \mathrm{M} \text { caused } 27 \% \text { OVCAR-3 cell death }\end{array}$ & (Gao et al., 2014) \\
\hline Osteosarcoma & $\begin{array}{l}24 \mathrm{~h} \\
48 \mathrm{~h} \\
72 \mathrm{~h}\end{array}$ & $\begin{array}{l}0.80 \mu \mathrm{M} I \mathrm{IC}_{50} \text { against MNNG } \\
0.54 \mu \mathrm{M} \mathrm{IC}_{50} \text { against 143B } \\
0.39 \mu \mathrm{M} \mathrm{IC}_{50} \text { against } \mathrm{MNNG} \\
0.31 \mu \mathrm{M} I \mathrm{C}_{50} \text { against } 143 \mathrm{~B} \\
0.32 \mu \mathrm{M} \mathrm{IC}_{50} \text { against MNNG } \\
0.29 \mu \mathrm{M} \mathrm{IC}_{50} \text { against } 143 \mathrm{~B}\end{array}$ & (Mori et al., 2017) \\
\hline Oral cancer & $72 \mathrm{~h}$ & $\begin{array}{l}0.54 \mu \mathrm{M} I \mathrm{C}_{50} \text { against } \mathrm{KB} \\
0.52 \mu \mathrm{M} I \mathrm{C}_{50} \text { against } \mathrm{KBv} 200 \\
0.70 \mu \mathrm{M} I \mathrm{C}_{50} \text { against } \mathrm{CAL}-27 \\
0.73 \mu \mathrm{M} I \mathrm{C}_{50} \text { against SCC-25 }\end{array}$ & $\begin{array}{l}\text { (Yan et al., 2017) } \\
\text { (Wu et al., 2019) }\end{array}$ \\
\hline ESCC & $72 \mathrm{~h}$ & $\begin{array}{l}1.98 \mu \mathrm{M} I \mathrm{IC}_{50} \text { against EC9706 } \\
1.76 \mu \mathrm{M} \mathrm{IC}_{50} \text { against EC109 } \\
1.13 \mu \mathrm{M} \mathrm{IC}_{50} \text { against KYSE30 }\end{array}$ & (Tu et al., 2018) \\
\hline
\end{tabular}

ESCC, esophageal squamous cell carcinoma.

the associated induction of JNK activation and MMP loss was observed (Yousef et al., 2016b), similar with the results in cervical cancer cells (Byun et al., 2009).

In human colon cancer cells, pristimerin caused cell cycle arrest and apoptosis through cyclin-CDK, mitochondrial dysfunction, and caspase-dependent mechanisms. Besides, the inhibition of DNA synthesis in HL-60 was also associated with pristimerin-induced apoptosis (Costa et al., 2008).

Pristimerin-induced apoptosis could be mediated by microRNA (miRNA). miRNAs exert a post-transcriptional gene silencing effect through binding to target mRNA and endonucleolytic cleavage of the mRNA by protein argonaute- 2 (AGO2) (Kobayashi and Tomari, 2016). It was reported that pristimerin induced apoptosis through inhibiting AGO2 and PTPN1 expression via miR-542-5p in glioma cancer cells U373 (Li et al., 2019). Synergization with cisplatin, pristimerin led to apoptosis via inhibiting the miR-23a, regulating PTEN/ Akt signaling-related PTEN and the phosphorylation of Akt and GSK3 $\beta$ in lung carcinoma NCI-H446 and A549 cells (Zhang et al., 2019).

\section{Autophagy Induction}

As another programmed necrosis, autophagy is a homeostatic cellular self-digestive process. Autophagy triggered by various cellular stress plays vital role in cell death, providing novel target for developing anti-cancer drug (Mizushima et al., 2008; Ravanan et al., 2017). LC3-II promotes the expansion and maturation of autophagy, which is considered as signal of autophagy activation. Pristimerin-induced autophagy was reported in human breast cancer MDA-MB-231 (Cevatemre et al., 2018; Lee et al., 2018) and MCF-7 cells (Cevatemre et al., 2018). As evidenced by the increase of p62 and LC3-II with an unfolded protein response (UPR), pristimerin induced an incompleted autophagy through Wnt signaling. Although endoplasmic reticulum (ER) stress is also a trigger of autophagy (Smith and 
Wilkinson, 2017), it was not concluded whether the observed ER stress by pristimerin induced autophagy (Cevatemre et al., 2018). Additionally, a combination treatment of pristimerin and paclitaxel strengthened the extracellular signal-related kinase (ERK)-dependent autophagic cell death, with increase of p62 degradation and beclin1 expression (Lee et al., 2018).

On the contrary, pristimerin suppressed autophagy, downregulating LC3BII and beclin1 to sensitize the apoptosis caused by cisplatin in lung carcinoma A549 and NCI-H446 cells (Zhang et al., 2019).

\section{Inhibition of Metastasis, Migration, Invasion, Angiogensis, and Cancer Stem Cell}

The cancer metastases include a series of process, such as the completion of a complex succession of cell-biological event, cancer cell invasion, migration, and forming metastatic colonization in clinic (Valastyan and Weinberg, 2011). Pristimerin was reported to inhibit migration and invasion via targeting $G$ protein signaling 4 (RGS4) in breast cancer MDA-MB-231 cells (Mu et al., 2012a) and HER2 in human breast carcinoma SKBR3 cells (Lee et al., 2013). Furthermore, mammalian target of rapamycin (mTOR) may be associated with its upstream Akt in pristimerin-induced inhibition of migration and invasion in colorectal cancer HCT-116 cells (Yousef et al., 2016b). Pristimerin suppressed the invasion of human prostate cancer PC-3 cells through inhibition of epithelial-to-mesenchymal transition (EMT), which was confirmed by the EMT-related markers (Chaffer et al., 2016), including N-cadherin, fibronectin, vimentin and ZEB1 (Zuo et al., 2015). MMP2 and MMP9, which are important proteins regulating invasion and metastasis, were decreased by pristimerin in esophageal cancer EC9706 and EC109 cells in a dose-dependent manner, resulting in inhibition of migration and invasion (Tu et al., 2018).

To supply nutrients and clear metabolic wastes, novel capillary blood vessels grow from pre-existing vasculature, which is called angiogenesis. However, aberrant angiogenesis plays a key role in cancer development (Valastyan and Weinberg, 2011). Thus, anti-angiogenic therapy is promising and under development (Li et al., 2018). Pristimerin was reported to in vivo inhibit the neovascularization of chicken chorioallantoic membrane (CAM) and vessel ex vivo sprout in rat aortic ring assay, through a vascular endothelial growth factor (VEGF)-dependent mechanism (Mu et al., 2012b). Also, the decreased-VEGF by pristimerin was reported through the inhibition of HIF-1a via the SPHK-1 signaling pathway in hypoxic prostate cancer PC-3 cells (Lee et al., 2016). In addition, pristimerin-induced cancer stem cell toxicity was observed in breast cancer stem cells (Cevatemre et al., 2018) and esophageal squamous cell carcinoma (ESCC) (Tu et al., 2018).

\section{Reversal of Drug Resistance}

Multi-drug resistance (MDR) is defined as the resistance of cancer cells not limited to a specific chemotherapeutic drug through different structures and mechanisms of action (Wu et al., 2014). $\mathrm{ABCB} 1$ (P-glycoprotein, Pgp) is recognized as putative drug transporter, which is encoded by the $\mathrm{ABCB} 1$ gene, one of (ATP)binding cassette (ABC) transporter family (Dewanjee et al., 2017). Pristimerin may overcome ABCB1-mediated chemotherapeutic drug resistance through disturbing the stability of $\mathrm{ABCB} 1$ independent of its mRNA expression in human oral epidermoid carcinoma cells KBv200 (Yan et al., 2017). In addition, with inhibition of $\mathrm{NF}-\kappa \mathrm{B}$ and $\mathrm{Bcr}-\mathrm{Abl}$, pristimerin is effective in vitro and in vivo against imatinib-resistant chronic myelogenous leukemia cells ( $\mathrm{Lu}$ et al., 2010). Additionally, Akt signaling was related to the reversal of MDR in multidrug-resistant MCF-7/ ADR breast cancer cells (Xie et al., 2016).

\section{Synergization With Chemotherapeutic Drugs}

Drug combination for cancer treatment has been well established to strengthen the anti-tumor action in varied aspects (Ho and Cheung, 2014; Andre et al., 2018), including therapeutic drug combination with natural product (Efferth, 2017; Sanchez et al., 2019). Pristimerin was reported to synergize with paclitaxel in human breast cancer cells (Lee et al., 2018), with 5-fluorouracil (5-FU) in esophageal ESCC (Tu et al., 2018). In cervical cancer cells, combination with taxol could induce cell death through ROS-mediated mitochondrial dysfunction (Eum et al., 2011). In NCI-H446 and A549 lung carcinoma cells, combination with cisplatin could induce cell apoptosis through inhibiting the miRNA-23a and Akt/GSK3 $\beta$ signaling pathway (Zhang et al., 2019). In pancreatic cancer cells, pristimerin could potentiate the cytotoxic effect of gemcitabine with the possible mechanism being the inhibition of gemcitabine-induced NF- $\kappa \mathrm{B}$ activation (Wang et al., 2012).

\section{In Vivo Anti-Tumor Activities}

Pristimerin was widely reported its in vivo anti-tumor activities, which is summarized in Table 2.

\section{PRISTIMERIN IN TUMORS: TARGETS AND PATHWAYS}

\section{Proteasome}

As another important mechanism of maintaining homeostasis, proteasome-mediated degradation is associated with essential cellular processes, regulating the vast majority of cellular proteins (Livneh et al., 2016). Consistent with triterpenoids being reported to target proteasome (Chintharlapalli et al., 2007; Tiedemann et al., 2009), pristimerin also showed a potent activity to inhibit proteasome activity in prostate cancer cells (Yang et al., 2010; Liu et al., 2013; Liu et al., 2014), breast cancer cells (Mu et al., 2012a), cervical carcinoma cells (Eum et al., 2011), and myeloma cells (Tiedemann et al., 2009).

The $\beta$ subunits of proteasome contain active protease sites with different peptidase activities, including caspase-like or peptidylglutamyl peptide-hydrolyzing-like $(\beta 1)$, trypsin-like post basic $(\beta 2)$, and chymotrypsin-like ( $\beta 5)$ activities (Mayor et al., 2016). 
TABLE 2 | In vivo anti-tumor activities of pristimerin.

\begin{tabular}{|c|c|c|c|c|}
\hline Models & Dose and administration & Activities & Mechanisms & References \\
\hline $\begin{array}{l}\text { Human breast tumor xenograft } \\
\text { model }\end{array}$ & 3 mg/kg/2 days, s.c. & $\begin{array}{l}\text { Reduced both tumor volume and } \\
\text { tumor weight, inhibited tumor } \\
\text { angiogenesis. }\end{array}$ & $\begin{array}{l}\text { Associated with decreased } \\
\text { secretion of proangiogenic } \\
\text { molecules (VEGF) }\end{array}$ & (Mu et al., 2012b) \\
\hline $\begin{array}{l}\text { Human breast tumor xenograft } \\
\text { model }\end{array}$ & 1 mg/kg/2 days, s.c. & $\begin{array}{l}\text { Inhibited the growth of implanted } \\
\text { tumors, inhibited the invasiveness }\end{array}$ & - & (Mu et al., 2012a) \\
\hline $\begin{array}{l}\text { Orthotopic HCC patient- } \\
\text { derived xenograft model }\end{array}$ & 1 mg/kg/3 times/week, i.v. & $\begin{array}{l}\text { Caused significant reductions in } \\
\text { tumor volumes of xenografts }\end{array}$ & $\begin{array}{l}\text { Disrupt HSP90 and CDC37 } \\
\text { interaction, inhibit Raf/MEK/ERK } \\
\text { and PI3K/AKT/mTOR pathways }\end{array}$ & (Wei et al., 2014) \\
\hline Intra-tibial injection model & $\begin{array}{l}7.5 \times 10^{3} \text { cells } / \mu \mathrm{l} 1.6 \mu \mathrm{M} \\
\text { pristimerin pre-treated } 24 \mathrm{~h} \\
\text { PC-3 cells }\end{array}$ & $\begin{array}{l}\text { Inhibited the bone destruction } \\
\text { by the invasion of the tumor, } \\
\text { reduced the tumorigenic potential } \\
\text { of bone metastasis }\end{array}$ & - & (Huang et al., 2015) \\
\hline $\begin{array}{l}\text { Human glioma xenograft } \\
\text { model }\end{array}$ & 1 and 3 mg/kg/2 days, s.c. & $\begin{array}{l}\text { Inhibited glioma volume and } \\
\text { weight in vivo in a dose- } \\
\text { dependent manner }\end{array}$ & $\begin{array}{l}\text { Up-regulated JNK level } \\
\text { the phosphorylated JNK, } \\
\text { upregulated the nuclear AIF and } \\
\text { the ratio of Bax/Bcl- } 2\end{array}$ & (Zhao et al., 2016) \\
\hline $\begin{array}{l}\text { AOM/DSS model of colitis- } \\
\text { associated colorectal } \\
\text { carcinogenesis }\end{array}$ & $\begin{array}{l}\text { fed with } 1 \text { to } 5 \text { ppm } \\
\text { pristimerin }\end{array}$ & Reduced tumor burden & - & (Park and Kim, 2018) \\
\hline $\begin{array}{l}\text { Human ESCC xenograft } \\
\text { model }\end{array}$ & $1 \mathrm{mg} / \mathrm{kg} / 2$ days, i.t. & $\begin{array}{l}\text { Inhibited the growth and weight } \\
\text { of tumor, suppressed proliferation }\end{array}$ & - & (Tu et al., 2018) \\
\hline $\begin{array}{l}\text { Human colorectal cancer } \\
\text { xenograft model }\end{array}$ & 1 mg/kg/2 days, i.p. & Inhibited tumor growth & $\begin{array}{l}\text { Mainly through suppressing } \\
\text { NF-кB activity and p65 } \\
\text { phosphorylation }\end{array}$ & (Yousef et al., 2018) \\
\hline $\begin{array}{l}\text { Human lung tumors xenograft } \\
\text { model }\end{array}$ & $\begin{array}{l}0.8 \mathrm{mg} / \mathrm{kg} \text { pristimerin and } \\
2 \mathrm{mg} / \mathrm{kg} \text { cisplatin, s.c. }\end{array}$ & $\begin{array}{l}\text { Enhanced the effect of cisplatin } \\
\text { to decrease tumor volumes and } \\
\text { weights }\end{array}$ & $\begin{array}{l}\text { Inhibited the phosphorylation of } \\
\text { Akt and GSK3 } \beta\end{array}$ & (Zhang et al., 2019) \\
\hline $\begin{array}{l}\text { Human osteosarcoma } \\
\text { xenograft model }\end{array}$ & 1 mg/kg/2 days, i.p. & $\begin{array}{l}\text { Reduced both tumor volume and } \\
\text { tumor weight }\end{array}$ & - & (Mori et al., 2017) \\
\hline $\begin{array}{l}\text { Human colorectal cancer } \\
\text { xenograft model }\end{array}$ & 1 mg/kg/2 days, i.p. & $\begin{array}{l}\text { Inhibited the growth of } \\
\text { implanted tumors }\end{array}$ & $\begin{array}{l}\text { Induced apoptosis through an } \\
\text { increment in cleaved caspase-3 }\end{array}$ & (Yousef et al., 2016b) \\
\hline $\begin{array}{l}\text { Human myeloma xenograft } \\
\text { model }\end{array}$ & 2.5 mg/kg per day, s.c. & $\begin{array}{l}\text { Inhibited growth of human } \\
\text { myeloma xenograft, diminished } \\
\text { toxicity in a liposomal dose }\end{array}$ & - & (Tiedemann et al., 2009) \\
\hline $\begin{array}{l}\text { Human breast cancer } \\
\text { xenograft model }\end{array}$ & 1 mg/kg for 2 days, i.p. & $\begin{array}{l}\text { Decreased tumor size and } \\
\text { weights, slightly reduced toxicity } \\
\text { and behavioral changes in an } \\
\text { E/T80/WFI carrier compared to } \\
\text { D/PBS. }\end{array}$ & - & (Cevatemre et al., 2018) \\
\hline
\end{tabular}

*s.c. represents subcutaneously, i.v. for intravenously, i.t. for intratumorly, i.p. for intraperitoneally, and ppm for parts per million, respectively. ERK, extracellular signal-related kinase.

Pristimerin was associated with the N-terminal threonine of the $\beta 5$ subunit through its conjugated ketone carbon $\mathrm{C}_{6}$, exerting a chymotrypsin-like activity (Yang et al., 2010), which is also associated with RGS4 (Mu et al., 2012a).

Pristimerin can inhibit Bcl-2, finally induced mitochondrial cell death via an ROS-dependent ubiquitin-proteasomal degradation pathway (Liu et al., 2013). Pristimerin combination with taxol caused mitochondrial apoptosis due to ROS generation and direct proteasome inhibition (Eum et al., 2011). In addition, pristimerininduced inhibition of proteosome and IKK phosphorylation of IкB together led to UPR and suppression of NF- $\kappa$ B activity and cyclin D2 expression in myeloma cells H929 and U266 (Tiedemann et al., 2009).

\section{Telomerase}

Telomere is a ribonucleoprotein complex located in the end of chromosomes, maintaining telomere length homeostasis to keep chromosomal stability (Wang and Feigon, 2017). Due to the differences in telomere homeostasis between cancer and normal cells, targeting telomerase may be a promising approach to find effective and safe anti-cancer treatments (Armstrong and Tomita, 2017).

Pristimerin can inhibit telomerase activity in human prostate cancer LNCaP and PC-3 cells (Liu et al., 2015). The mechanism is related to inhibition of human telomerase reverse transcriptase (hTERT) and its mRNA expression, which codes the catalytic subunit of the telomerase. At the same time, knocking-down of hTERT strengthened the effects of pristimerin. Furthermore, hTERT regulatory proteins $\mathrm{c}-\mathrm{Myc}, \mathrm{Sp} 1, \mathrm{p}$-STAT3, and p-Akt were inhibited in a dose-dependent manner (Liu et al., 2015).

\section{MAPK Pathway}

The generic MAPK signaling pathway is co-regulated by four different cascades including extracellular signal-related kinases (ERK1/2), Jun amino-terminal kinases (JNK1/2/3), p38-MAPK, 
and ERK5 (Sun et al., 2015). MAPK/ERK pathway regulates the cell proliferation (Sun et al., 2017), differentiation (Wang et al., 2017), migration (Tao et al., 2018) and apoptosis (Wang and Zhu, 2018).

Pristimerin-induced autophagy was reported via ERK1/2 in human breast cancer cells when combination with paclitaxel (Lee et al., 2018). ERK1/2 may be involved in pristimerininduced intrinsic apoptosis in human oral epidermoid carcinoma cells (Yan et al., 2017) and in human glioma cells (Yan et al., 2013). Both JNK and PARP-1 via ROS pathway are essentially required for the pristimerin-induced intrinsic apoptosis in human cervical cancer cells (Byun et al., 2009). In addition, ERK1/2 suppression occurred in VEGF-induced capillary-like structure formation of human umbilical vascular endothelial cells (HUVECs) (Mu et al., 2012b). These activities were accompanied with Akt inhibition ( $\mathrm{Mu}$ et al., 2012b; Yan et al., 2017; Lee et al., 2018).

\section{PI3K/AKT/mTOR Pathway}

The phosphatidylinositol 3-kinase (PI3K)/AKT/mTOR pathway cascade containing PI3K, AKT, and mTOR is the most frequently altered pathway in human for cancer development, such as cell cycle, cell survival, metabolism, motility, angiogenesis, chemoresistance, and genomic instability (Mabuchi et al., 2015).

Pristimerin showed a potent apoptosis-inducing antiproliferative activity in human osteosarcoma cells (Mori et al., 2017) by PI3K/AKT/mTOR pathway. The pristimerin-induced ROS-dependent mitochondrial cell apoptosis was also associated with the inhibition of EGFR and Akt in human glioma cells (Yan et al., 2013). It was confirmed that PI3K/AKT/mTOR pathwayactivated activities were accompanied by the downstream Foxo-3a, cyclin D1 and Bcl-XL (Akt), p-S6K1, and p-4E-BP1 (mTOR) as well as p21, p27, and PKCe in human ovarian cancer cells (Deeb et al., 2014b; Gao et al., 2014; Park and Kim, 2018). Furthermore, downstream Bad and Bcl-xL pointed to drug resistance in MCF-7/ADR human breast cancer cells (Xie et al., 2016). In addition, pristimerin suppressed angiogenesis through VEGF-induced Akt, ERK1/2, mTOR, and ribosomal protein S6 kinase (Mu et al., 2012b).

\section{NF-кB Pathway}

NF- $\kappa B$ family transcription factors are crucial regulators of cell survival and inflammatory processes (Napetschnig and Wu, 2013). The inactive NF- $\kappa$ Bs are isolated from nucleus by inhibitor of NF- $\kappa B(I \kappa B)$ proteins. When activated IKK (I $\kappa$ B kinase) makes a proteasomal degradation of $I \kappa B$, the subsequent process will occur, including the release of NF- $\kappa \mathrm{B}$, translocation of NF- $\kappa \mathrm{B}$ nuclear and activation of gene transcription. NF- $\kappa \mathrm{B}$ can be activated by both intracellular and extracellular stimuli, including cytokines (TNFa, IL-1 $\beta$ ), bacterial, and viral products (LPS) (Xia et al., 2014).

NF- $\kappa \mathrm{B}$-regulated anti-apoptotic Bcl-2, Bcl-xL, c-IAPl, and surviving in human ovarian carcinoma cells (Gao et al., 2014), Cox-2 and VEGF in human pancreatic cancer cells (Deeb et al., 2014b). NF- $\kappa$ B pathway may link anti-tumor activity of pristimerin and its anti-inflammatory properties (Park and
Kim, 2018). Pristimerin suppressed the translocation of NF- $\kappa B$ nuclear; however, there was no change of the total NF- $\kappa B$ protein in pancreatic cancer (Wang et al., 2012). In contrast, pristimerin inhibited both genetic expression and activation of NF- $\mathrm{\kappa B}$ protein with suppression of p65 mRNA in human colorectal cancer cells (Yousef et al., 2018). TNFa-induced NF- $\kappa$ B activation was observed by the downstream MMP9, cyclin D1, and c-Myc in ESCC cells (Tu et al., 2018). When combined with pristimerin, the inactivation of $\mathrm{Bcr}-\mathrm{Abl}$ by imatinib did not interfere with the $\mathrm{TNF} \alpha$-induced NF- $\mathrm{KB}$ activation, which implicated that $\mathrm{NF}-\kappa \mathrm{B}$ inactivation and $\mathrm{Bcr}-\mathrm{Abl}$ inhibition may be parallel mechanisms of pristimerin-induced activity in human chronic myelogenous leukemia cells ( $\mathrm{Lu}$ et al., 2010). G1 phase arrest was also associated with NF- $\kappa \mathrm{B}$ pathway in human pancreatic cancer cells (Wang et al., 2012), as well as proteosome in human myeloma cells (Tiedemann et al., 2009). Moreover, pristimerin inhibited expression of miR-542-5p targeting PTPN1, which encodes protein tyrosine phosphatase $1 \mathrm{~B}$ (PTP1B) related to NF- $\kappa B$ pathway (Li et al., 2019).

\section{Wnt/ק-Catenin Pathway}

Wnt proteins are key mediators in a series of important cellular process. The abnormal activation of $\mathrm{Wnt} / \beta$-catenin pathway can cause a wide range of diseases including cancers (Krishnamurthy and Kurzrock, 2018; Pedone and Marucci, 2019). Pristimerin was reported to suppress $\mathrm{Wnt} / \beta$-catenin pathway through targeting and inhibiting the expression of LRP6 and its phosphorylation, which may contribute to autophagy in human breast cancer MCF-7 cells (Cevatemre et al., 2018).

\section{CONCLUSIONS AND PERSPECTIVE}

Plants, particularly medicinal herbs, have become increasingly popular due to their potent therapeutic effects. Pristimerin, a quininemethide triterpenoid compound isolated from species of the Celastraceae and Hippocrateaceae families, has displayed biological and pharmacological activities, particularly inhibiting cancer. This review summarizes the reported results on anticancer activities and related mechanisms of pristimerin.

Pristimerin has shown anti-cancer potency in vivo (Table 2) and in vitro (Table 3) via specific mechanisms (Figure 2). Like many other chemotherapeutic drugs, pristimerin exerts cytotoxicity largely related to apoptosis, while the mechanism of autophagy is merely reported. The cross-talk of apoptosis and autophagy mediated by pristimerin is still remained to be explored. So far, the mechanism study of pristimerin has little reported on lung cancer, epigenetic regulation, and combination with immunotherapy. Furthermore, pristimerin has been reported to have poor selective toxicity in some cancer cells or compared with its derivatives (Costa et al., 2008; Wei et al., 2014). Comprehensive evaluation of pristimerin toxicity is yet to be carried out (as well as clinical trials). In summary, pristimerin possesses potent anti-cancer effect and further study will bring about novel drug development based on pristimerin. 
TABLE 3 | Anti-cancer mechanisms of pristimerin in different cell lines.

\begin{tabular}{|c|c|c|c|}
\hline Cancer type & Cell lines & Mechanisms & References \\
\hline \multirow[t]{5}{*}{ Prostate cancer } & PC-3 & Inhibited HIF-1 $\alpha$ accumulation by inhibiting SPHK-1 & \\
\hline & & Inhibited CD133 and CD44 protein expression, reduced VEGF & (Huang et al., 2015) \\
\hline & LNCaP and PC-3 & $\begin{array}{l}\text { Down-regulated Bcl-2 through an ROS-dependent ubiquitin-proteasomal } \\
\text { degradation pathway }\end{array}$ & (Liu et al., 2013) \\
\hline & & Prevented survivin via the ubiquitin-proteasome pathway & (Liu et al., 2014) \\
\hline & & Inhibited hTERT expression via the inhibition of SP1, c-Myc, STAT3, and B/Akt & (Liu et al., 2015) \\
\hline \multirow[t]{3}{*}{ Breast cancer } & SKBR3 & Down-regulated HER2, decreased fatty acid synthase & (Lee et al., 2013) \\
\hline & MDA-MB-231 & Suppressed proteasomal activity via increasing the levels of RGS4 & (Mu et al., 2012a) \\
\hline & & $\begin{array}{l}\text { Suppressed the LC3-II levels of this on ERK signaling when combination with } \\
\text { paclitaxel }\end{array}$ & (Lee et al., 2018) \\
\hline \multirow[t]{3}{*}{ Colorectal cancer } & HCT-116 & $\begin{array}{l}\text { Inhibited the AKT/FOXO3a pathway via decreasing cyclinD1 and } \mathrm{Bcl}-\mathrm{XL} \text {, increased } \\
\text { the expression of p21 and p27 }\end{array}$ & (Park and Kim, 2018) \\
\hline & HCT-116 & Inhibited activated NF-кB, TNF $\alpha$, and activated LPS-induced NF-кB signaling pathway & (Yousef et al., 2018) \\
\hline & $\begin{array}{l}\text { HCT-116, COLO-205, and } \\
\text { SW-620 }\end{array}$ & $\begin{array}{l}\text { Inhibited of phosphorylated EGFR and HER2 expression, caused inhibition of } \\
\text { related downstream kinases. }\end{array}$ & (Yousef et al., 2016a) \\
\hline \multirow[t]{2}{*}{$\begin{array}{l}\text { Hepatocellular } \\
\text { carcinoma }\end{array}$} & HepG2 & $\begin{array}{l}\text { Generated ROS, induced release of cytochrome c, and down-regulated EGFR } \\
\text { protein }\end{array}$ & (Guo et al., 2013) \\
\hline & & $\begin{array}{l}\text { Disrupted HSP90/CDC37 interaction, degraded and inhibited phosphorylation of } \\
\text { protein kinases in the Raf/MEK/ERK and PI3K/AKT/mTOR signaling pathways }\end{array}$ & (Wei et al., 2014) \\
\hline \multirow[t]{2}{*}{ Pancreatic cancer } & BxPC-3, PANC-1, and AsPC-1 & Inhibited of the translocation and DNA-binding activity of NF- $\mathrm{kB}$ & (Wang et al., 2012) \\
\hline & MiaPaCa-2 and Panc-1 & Inhibited of hTERT via suppressing the transcription factors Sp1, c-Myc, and NF-кB & (Deeb et al., 2015) \\
\hline \multirow[t]{2}{*}{ Glioma } & U87 & Activated of JNK through overproduction of ROS & (Zhao et al., 2016) \\
\hline & U373 & Targeting AGO2 and PTPN1 expression via miR-542-5p & (Li et al., 2019) \\
\hline Myeloma & H929 and U266 & $\begin{array}{l}\text { Both inhibited IKK phosphorylation of } I_{\kappa B} \text { and proteosome, causing unfolded } \\
\text { protein response and suppressing NF- } \mathrm{KB} \text { activity and cyclin D expression }\end{array}$ & $\begin{array}{l}\text { (Tiedemann et al., } \\
\text { 2009) }\end{array}$ \\
\hline Cervical cancer & HeLa & Activated ROS-dependent JNK, Bax, and PARP-1 & (Eum et al., 2011) \\
\hline \multirow[t]{2}{*}{ Leukemia } & HL-60 & Interfered DNA synthesis & (Costa et al., 2008) \\
\hline & KBM5 and KBM5-T3151 & $\begin{array}{l}\text { Depleted Bcr-Abl, activated TAK1TIKK and IKKTIкB } \alpha \text { in NF-KB signaling parallel but } \\
\text { independent }\end{array}$ & (Lu et al., 2010) \\
\hline Ovarian carcinoma & $\begin{array}{l}\text { OVCAR-5, MDAH-2774, } \\
\text { OVCAR-3, and SK-OV-3 }\end{array}$ & $\begin{array}{l}\text { Inhibited prosurvival signaling proteins Akt, mTOR and NF-kB; inhibited NF-кB- } \\
\text { regulated anti-apoptotic proteins } \mathrm{Bcl}-2, \mathrm{Bcl}-\mathrm{xL}, \mathrm{c}-\mathrm{API} \text { and survivin }\end{array}$ & (Gao et al., 2014) \\
\hline Osteosarcoma & MNNG and 143B & Decreased expression of Akt, mTOR, and NF-кB & (Mori et al., 2017) \\
\hline \multirow[t]{2}{*}{ Oral cancer } & KBv200 & Decreased P-gp through interrupt protein stability in MAPK and PI3K/Akt pathways & (Yan et al., 2017) \\
\hline & CAL-27 and SCC-25 & G1 phase arrest and MAPK/Erk1/2 and Akt signaling inhibition & (Wu et al., 2019) \\
\hline ESCC & EC9706, EC109, and KYSE30 & Inhibited NF-кB pathway, synergistic effect with 5-FU & (Tu et al., 2018) \\
\hline
\end{tabular}

ESCC, esophageal squamous cell carcinoma; ROS, reactive oxygen species.

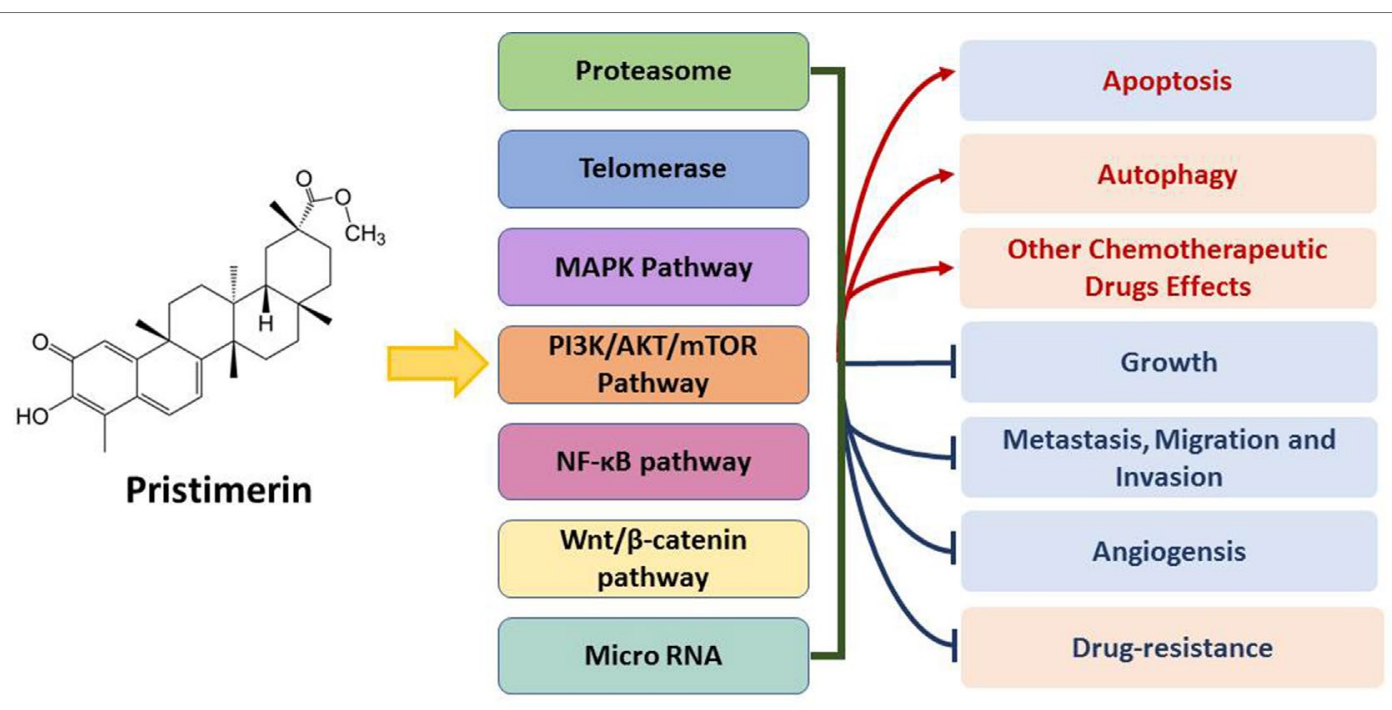

FIGURE 2 | Brief summary of anti-cancer mechanisms and activities of pristimerin. 


\section{DATA AVAILABILITY}

All datasets analyzed for this study are included in the manuscript and the supplementary files.

\section{AUTHOR CONTRIBUTIONS}

$\mathrm{JZ}$ and $\mathrm{HC}$ conceived this review; JL and YY wrote the article. $\mathrm{HS}, \mathrm{YL}$, and CS revised the article.

\section{REFERENCES}

Alessia, P., Gaetano, P., and Ugo, T. (2009). Triterpenoids as new promising anticancer drugs. Anticancer Drugs 20, 880-892. doi: 10.1097/CAD. 0b013e328330fd90

Andre, P., Denis, C., Soulas, C., Bourbon-Caillet, C., Lopez, J., Arnoux, T., et al. (2018). Anti-NKG2A mAb is a checkpoint inhibitor that promotes anti-tumor immunity by unleashing both $\mathrm{T}$ and NK cells. Cell 175, 1731-1743. doi: 10.1016/j.cell.2018.10.014

Armstrong, C. A., and Tomita, K. (2017). Fundamental mechanisms of telomerase action in yeasts and mammals: understanding telomeres and telomerase in cancer cells. Open Biol. 7, 160338. doi: 10.1098/rsob.160338

Avilla, J., Teixidò, A., Velázquez, C., Alvarenga, N., Ferro, E., and Canela, R. (2000). Insecticidal activity of Maytenus Species (Celastraceae) Nortriterpene Quinone Methides against codling moth, Cydia pomonella (L). (Lepidoptera: Tortricidae). J. Agric. Food Chem. 48, 88-92. doi: 10.1021/jf990008w

Brattain, M. G., Howell, G., Sun, L. Z., and Willson, J. K. (1994). Growth factor balance and tumor progression. Curr. Opin. Oncol. 6, 77-81. doi: 10.1097/00001622-199401000-00011

Byun, J.-Y., Kim, M.-J., Eum, D.-Y., Yoon, C.-H., Seo, W.-D., Park, K. H., et al. (2009). Reactive oxygen species-dependent activation of Bax and Poly(ADPribose) polymerase-1 is required for mitochondrial cell death induced by triterpenoid pristimerin in human cervical cancer cells. Mol. Pharmacol. 76, 734-744. doi: 10.1124/mol.109.056259

Cevatemre, B., Erkısa, M., Aztopal, N., Karakas, D., Alper, P., Tsimplouli, C., et al. (2018). A promising natural product, pristimerin, results in cytotoxicity against breast cancer stem cells in vitro and xenografts in vivo through apoptosis and an incomplete autopaghy in breast cancer. Pharmacol. Res. 129, 500-514. doi: 10.1016/j.phrs.2017.11.027

Chaffer, C. L., San Juan, B. P., Lim, E., and Weinberg, R. A. (2016). EMT, cell plasticity and metastasis. Cancer Metastasis Rev. 35, 645-654. doi: 10.1007/ s10555-016-9648-7

Chintharlapalli, S., Papineni, S., Ramaiah, S. K., and Safe, S. (2007). Betulinic acid inhibits prostate cancer growth through inhibition of specificity protein transcription factors. Cancer Res. 67, 2816-2823. doi: 10.1158/0008-5472. CAN-06-3735

Costa, P. M. D., Ferreira, P. M. P., Bolzani, V. D. S., Furlan, M., Corsino, J., De Moraes, M. O., et al. (2008). Antiproliferative activity of pristimerin isolated from Maytenus ilicifolia (Celastraceae) in human HL-60 cells. Toxicol. In Vitro 22, 854-863. doi: 10.1016/j.tiv.2008.01.003

Deeb, D., Brigolin, C., Gao, X., Liu, Y., Pindolia, K. R., and Gautam, S. C. (2014a). Induction of Apoptosis in Pancreatic Cancer Cells by CDDO-Me Involves repression of telomerase through epigenetic pathways. J. Carcinog. Mutagen. 5, 177. doi: 10.4172/2157-2518.1000177

Deeb, D., Gao, X., Liu, Y., Kim, S. H., Pindolia, K. R., Arbab, A. S., et al. (2012). Inhibition of cell proliferation and induction of apoptosis by oleanane triterpenoid (CDDO-Me) in pancreatic cancer cells is associated with the suppression of hTERT gene expression and its telomerase activity. Biochem. Biophys. Res. Commun. 422, 561-567. doi: 10.1016/j.bbrc.2012.05.024

Deeb, D., Gao, X., Liu, Y., Pindolia, K., and Gautam, S. C. (2015). Inhibition of hTERT/telomerase contributes to the antitumor activity of pristimerin in pancreatic ductal adenocarcinoma cells. Oncol. Rep. 34, 518-524. doi: 10.3892/ or.2015.3989

\section{FUNDING}

The work was supported by National Natural Science Foundation of China (81473320 and 81773888), Fund of Guangdong Science and Technology Department (2016A020226024), Fund of Guangzhou Science and Technology Program (201707010048), Fund of Guangdong Education Department (2015KTSCX112), and Fund of Construction of High Level Universities in Guangdong (Nanshan Scholars Program and Academic Backbone Program).

Deeb, D., Gao, X., Liu, Y. B., Pindolia, K., and Gautam, S. C. (2014b). Pristimerin, a quinonemethide triterpenoid, induces apoptosis in pancreatic cancer cells through the inhibition of pro-survival Akt/NF-kappaB/mTOR signaling proteins and anti-apoptotic Bcl-2. Int. J. Oncol. 44, 1707-1715. doi: 10.3892/ ijo.2014.2325

Dent, M.a.R., and Aranda-Anzaldo, A. (2019). Lessons we can learn from neurons to make cancer cells quiescent. J. Neurosci. Res. doi: 10.1002/jnr.24428

Dewanjee, S., Dua, T. K., Bhattacharjee, N., Das, A., Gangopadhyay, M., Khanra, R., et al. (2017). Natural products as alternative choices for P-glycoprotein (P-gp) Inhibition. Molecules 22, 871. doi: 10.3390/molecules22060871

Dorstyn, L., Akey, C. W., and Kumar, S. (2018). New insights into apoptosome structure and function. Cell Death Differ. 25, 1194-1208. doi: 10.1038/ s41418-017-0025-z

Efferth, T. (2017). Cancer combination therapies with artemisinin-type drugs. Biochem. Pharmacol. 139, 56-70. doi: 10.1016/j.bcp.2017.03.019

Elmore, S. (2007). Apoptosis: a review of programmed cell death. Toxicol. Pathol. 35, 495-516. doi: 10.1080/01926230701320337

Estaquier, J., Vallette, F., Vayssiere, J. L., and Mignotte, B. (2012). The mitochondrial pathways of apoptosis. Adv. Exp. Med. Biol. 942, 157-183. doi: 10.1007/978-94-007-2869-1_7

Eum, D.-Y., Byun, J.-Y., Yoon, C.-H., Seo, W.-D., Park, K.-H., Lee, J.-H., et al. (2011). Triterpenoid pristimerin synergizes with taxol to induce cervical cancer cell death through reactive oxygen species-mediated mitochondrial dysfunction. Cell Death Dis. 22, 763-773. doi: 10.1097/CAD.0b013e328347181a

Figueiredo, J. B., and Sequin, U. (1998). Novel quinone methides from Salacia kraussii with in vitro antimalarial activity. J. Nat. Prod. 61, 718-723. doi: $10.1021 / \mathrm{np} 9704157$

Gao, X., Liu, Y., Deeb, D., Arbab, A. S., and Gautam, S. C. (2014). Anticancer activity of pristimerin in ovarian carcinoma cells is mediated through the inhibition of prosurvival Akt/NF-kappaB/mTOR signaling. J. Exp. Ther. Oncol. $10,275-283$

Guo, Y., Zhang, W., Yan, Y. Y., Ma, C. G., Wang, X., Wang, C., et al. (2013). Triterpenoid pristimerin induced HepG2 cells apoptosis through ROSmediated mitochondrial dysfunction. J. BUON. 18, 477-485.

Gupta, S. (2001). Molecular steps of death receptor and mitochondrial pathways of apoptosis. Life Sci. 69, 2957-2964. doi: 10.1016/S0024-3205(01)01404-7

Haroldo Jeller, A., Helena Siqueira Silva, D., Morais Lião, L., Da Silva Bolzani, V., and Furlan, M. (2004). Antioxidant phenolic and quinonemethide triterpenes from Cheiloclinium cognatum. Phytochemistry 65, 1977-1982. doi: 10.1016/j. phytochem.2004.03.039

Ho, J. W., and Cheung, M. W. (2014). Combination of phytochemicals as adjuvants for cancer therapy. Recent Pat. Anticancer Drug Discov. 9, 297-302. doi: 10.217 4/1574892809666140619154838

Huang, S., He, P., Peng, X., Li, J., Xu, D., and Tang, Y. (2015). Pristimerin inhibits prostate cancer bone metastasis by targeting PC-3 stem cell characteristics and VEGF-induced vasculogenesis of BM-EPCs. Cell. Physiol. Biochem. 37, 253268. doi: $10.1159 / 000430350$

Kale, J., Osterlund, E. J., and Andrews, D. W. (2018). BCL-2 family proteins: changing partners in the dance towards death. Cell Death Differ. 25, 65-80. doi: 10.1038/cdd.2017.186

Ke, B., Tian, M., Li, J., Liu, B., and He, G. (2016). Targeting programmed cell death using small-molecule compounds to improve potential cancer therapy. Med. Res. Rev. 36, 983-1035. doi: 10.1002/med.21398 
Kim, H. J., Park, G. M., and Kim, J.-K. (2013). Anti-inflammatory effect of pristimerin on lipopolysaccharide-induced inflammatory responses in murine macrophages. Arch. Pharm. Res. 36, 495-500. doi: 10.1007/s12272-013-0054-1

Kobayashi, H., and Tomari, Y. (2016). RISC assembly: coordination between small RNAs and argonaute proteins. Biochim. Biophys. Acta 1859, 71-81. doi: 10.1016/j.bbagrm.2015.08.007

Krishnamurthy, N., and Kurzrock, R. (2018). Targeting the Wnt/beta-catenin pathway in cancer: update on effectors and inhibitors. Cancer Treat. Rev. 62, 50-60. doi: 10.1016/j.ctrv.2017.11.002

Kulkarni, A. B., and Shah, R. C. (1954). Structure of pristimerin. Nature 173, 12371238. doi: 10.1038/1731237b0

Larsen, H., Muz, B., Khong, T. L., Feldmann, M., and Paleolog, E. M. (2012). Differential effects of Th1 versus Th2 cytokines in combination with hypoxia on HIFs and angiogenesis in RA. Arthritis Res. Ther. 14, R180. doi: 10.1186/ ar3934

Lee, J. S., Yoon, I. S., Lee, M. S., Cha, E. Y., Thuong, P. T., Diep, T. T., et al. (2013). Anticancer activity of pristimerin in epidermal growth factor receptor 2-positive SKBR3 human breast cancer cells. Biol. Pharm. Bull. 36, 316-325. doi: 10.1248/bpb.b12-00685

Lee, S.-O., Kim, J.-S., Lee, M.-S., and Lee, H.-J. (2016). Anti-cancer effect of pristimerin by inhibition of HIF-1a involves the SPHK-1 pathway in hypoxic prostate cancer cells. BMC Cancer 16, 701. doi: 10.1186/s12885-016-2730-2

Lee, Y., Lee, M., Cha, E., Sul, J., Park, J., and Lee, J. (2018). Combination of pristimerin and paclitaxel additively induces autophagy in human breast cancer cells via ERK1/2 regulation. Mol. Med. Rep. 18, 4281-4288. doi: 10.3892/mmr.2018.9488

Li, T., Kang, G., Wang, T., and Huang, H. (2018). Tumor angiogenesis and antiangiogenic gene therapy for cancer. Oncol. Lett. 16, 687-702. doi: 10.3892/ ol.2018.8733

Li, Z., Hu, C., Zhen, Y., Pang, B., Yi, H., and Chen, X. (2019). Pristimerin Inhibits Glioma Progression by Targeting AGO2 and PTPN1 Expression via miR542-5p. Biosci. Rep. 39. doi: 10.1042/BSR20182389

Lin, M., Tang, S., Zhang, C., Chen, H., Huang, W., Liu, Y., et al. (2017). Euphorbia factor L2 induces apoptosis in A549 cells through the mitochondrial pathway. Acta Pharm. Sin. B 7, 59-64. doi: 10.1016/j.apsb.2016.06.008

Liu, Y. B., Gao, X., Deeb, D., Arbab, A. S., and Gautam, S. C. (2013). Pristimerin Induces Apoptosis in Prostate Cancer Cells by Down-regulating Bcl-2 through ROS-dependent ubiquitin-proteasomal degradation pathway. J. Carcinog. Mutagen. Suppl 6, 5. doi: 10.4172/2157-2518.S6-005

Liu, Y. B., Gao, X., Deeb, D., Brigolin, C., Zhang, Y., Shaw, J., et al. (2014). Ubiquitinproteasomal degradation of antiapoptotic survivin facilitates induction of apoptosis in prostate cancer cells by pristimerin. Int. J. Oncol. 45, 1735-1741. doi: 10.3892/ijo.2014.2561

Liu, Y. B., Gao, X., Deeb, D., Pindolia, K., and Gautam, S. C. (2015). Role of telomerase in anticancer activity of pristimerin in prostate cancer cells. J. Exp. Ther. Oncol. 11, 41-49.

Livneh, I., Cohen-Kaplan, V., Cohen-Rosenzweig, C., Avni, N., and Ciechanover, A. (2016). The life cycle of the $26 \mathrm{~S}$ proteasome: from birth, through regulation and function, and onto its death. Cell Res. 26, 869-885. doi: 10.1038/cr.2016.86

Lopez, M. R., De Leon, L., and Moujir, L. (2011). Antibacterial properties of phenolic triterpenoids against Staphylococcus epidermidis. Planta. Med. 77, 726-729. doi: 10.1055/s-0030-1250500

Lu, Z., Jin, Y., Chen, C., Li, J., Cao, Q., Pan, et al. (2010). Pristimerin induces apoptosis in imatinib-resistant chronic myelogenous leukemia cells harboring T315I mutation by blocking NF- $\mathrm{B}$ signaling and depleting Bcr-Abl. Mol. Cancer 9, 112. doi: 10.1186/1476-4598-9-112

Mabuchi, S., Kuroda, H., Takahashi, R., and Sasano, T. (2015). The PI3K/AKT/ mTOR pathway as a therapeutic target in ovarian cancer. Gynecol. Oncol. 137, 173-179. doi: 10.1016/j.ygyno.2015.02.003

Mayor, T., Sharon, M., and Glickman, M. H. (2016). Tuning the proteasome to brighten the end of the journey. Am. J. Physiol., Cell Physiol. 311, C793-C804. doi: 10.1152/ajpcell.00198.2016

Mena-Rejon, G. J., Perez-Espadas, A. R., Moo-Puc, R. E., Cedillo-Rivera, R., Bazzocchi, I. L., Jimenez-Diaz, I. A., et al. (2007). Antigiardial activity of triterpenoids from root bark of Hippocratea excelsa. J. Nat. Prod. 70, 863-865. doi: 10.1021/np060559y

Mizushima, N., Levine, B., Cuervo, A. M., and Klionsky, D. J. (2008). Autophagy fights disease through cellular self-digestion. Nature 451, 1069. doi: 10.1016/j. cell.2004.11.046
Mori, Y., Shirai, T., Terauchi, R., Tsuchida, S., Mizoshiri, N., Hayashi, D., et al. (2017). Antitumor effects of pristimerin on human osteosarcoma cells in vitro and in vivo. Onco. Targets Ther. 10, 5703-5710. doi: 10.2147/OTT.S150071

Mu, X.-M., Shi, W., Sun, L.-X., Li, H., Wang, Y.-R., Jiang, Z.-Z., et al. (2012a). Pristimerin Inhibits Breast Cancer Cell Migration by Up-regulating Regulator of G Protein Signaling 4 Expression. Asian Pac. J. Cancer Prev. 13, 1097-1104. doi: 10.7314/APJCP.2012.13.4.1097

Mu, X., Shi, W., Sun, L., Li, H., Jiang, Z., and Zhang, L. (2012b). Pristimerin, a triterpenoid, inhibits tumor angiogenesis by targeting VEGFR2 activation. Molecules 17, 6854-6868. doi: 10.3390/molecules17066854

Murayama, T., Eizuru, Y., Yamada, R., Sadanari, H., Matsubara, K., Rukung, G., et al. (2007). Anticytomegalovirus activity of pristimerin, a triterpenoid quinone methide isolated from Maytenus heterophylla (Eckl. \& Zeyh). Antivir. Chem. Chemother. 18, 133-139. doi: 10.1177/095632020701800303

Napetschnig, J., and Wu, H. (2013). Molecular basis of NF-kappaB signaling. Annu. Rev. Biophys. 42, 443-468. doi: 10.1146/annurev-biophys-083012-130338

Park, J. H., and Kim, J. K. (2018). Pristimerin, a naturally occurring triterpenoid, attenuates tumorigenesis in experimental colitis-associated colon cancer. Phytomedicine 42, 164-171. doi: 10.1016/j.phymed.2018.03.033

Pecina-Slaus, N. (2009). Genetic and molecular insights into apoptosis. Acta Med. Croatica 63 Suppl 2, 13-19.

Pedone, E., and Marucci, L. (2019). Role of beta-catenin activation levels and fluctuations in controlling cell fate. Genes (Basel) 10, 176. doi: 10.3390/ genes 10020176

Peng, S., Hang, N., Liu, W., Guo, W., Jiang, C., Yang, X., et al. (2016). Andrographolide sulfonate ameliorates lipopolysaccharide-induced acute lung injury in mice by down-regulating MAPK and NF-kappaB pathways. Acta Pharm. Sin. B 6, 205-211. doi: 10.1016/j.apsb.2016.02.002

Petho, Z., Najder, K., Bulk, E., and Schwab, A. (2019). Mechanosensitive ion channels push cancer progression. Cell Calcium 80, 79-90. doi: 10.1016/j.ceca.2019.03.007

Qi, S., Guo, L., Yan, S., Lee, R. J., Yu, S., and Chen, S. (2019). Hypocrellin A-based photodynamic action induces apoptosis in A549 cells through ROS-mediated mitochondrial signaling pathway. Acta Pharm. Sin. B 9, 279-293. doi: 10.1016/j. apsb.2018.12.004

Ravanan, P., Srikumar, I. F., and Talwar, P. (2017). Autophagy: the spotlight for cellular stress responses. Life Sci. 188, 53-67. doi: 10.1016/j.lfs.2017.08.029

Salminen, A., Lehtonen, M., Suuronen, T., Kaarniranta, K., and Huuskonen, J. (2008). Terpenoids: natural inhibitors of NF- $\kappa B$ signaling with antiinflammatory and anticancer potential. Cell. Mol. Life Sci. 65, 2979-2999. doi: 10.1007/s00018-008-8103-5

Sanchez, B. G., Bort, A., Mateos-Gomez, P. A., Rodriguez-Henche, N., and DiazLaviada, I. (2019). Combination of the natural product capsaicin and docetaxel synergistically kills human prostate cancer cells through the metabolic regulator AMP-activated kinase. Cancer Cell Int. 19, 54. doi: 10.1186/s12935-019-0769-2

Shen, S., Dean, D. C., Yu, Z., and Duan, Z. (2019). Role of cyclin-dependent kinases (CDKs) in hepatocellular carcinoma: therapeutic potential of targeting CDKs signaling pathway. Hepatol. Res. doi: 10.1111/hepr.13353

Smith, M., and Wilkinson, S. (2017). ER homeostasis and autophagy. Essays Biochem. 61, 625-635. doi: 10.1042/EBC20170092

Sun, Q., Liang, Y., Zhang, T., Wang, K., and Yang, X. (2017). ER-alpha36 mediates estrogen-stimulated MAPK/ERK activation and regulates migration, invasion, proliferation in cervical cancer cells. Biochem. Biophys. Res. Commun. 487, 625-632. doi: 10.1016/j.bbrc.2017.04.105

Sun, Y., Liu, W. Z., Liu, T., Feng, X., Yang, N., and Zhou, H. F. (2015). Signaling pathway of MAPK/ERK in cell proliferation, differentiation, migration, senescence and apoptosis. J. Recept. Signal Transduct. Res. 35, 600-604. doi: 10.3109/10799893.2015.1030412

Tang, W.-H., Bai, S.-T., Tong, L., Duan, W.-J., Su, J.-W., Chen, J.-X., et al. (2014). Chemical constituents from Celastrus aculeatus Merr. Biochem. Syst. Ecol. 54, 78-82. doi: 10.1016/j.bse.2014.01.001

Tao, L., Zhang, C. Y., Guo, L., Li, X., Han, N. N., and Zhou, Q. (2018). MicroRNA-497 accelerates apoptosis while inhibiting proliferation, migration, and invasion through negative regulation of the MAPK/ERK signaling pathway via RAF-1. J. Cell. Physiol. 233, 6578-6588. doi: 10.1002/jcp.26272

Tao, Y. W., Lin, Y. C., She, Z. G., Lin, M. T., Chen, P. X., and Zhang, J. Y. (2015). Anticancer activity and mechanism investigation of beauvericin isolated from secondary metabolites of the mangrove endophytic fungi. Anticancer Agents Med. Chem. 15 (2), 258-266. doi: 10.2174/1871520614666140825112255 
Tiedemann, R. E., Schmidt, J., Keats, J. J., Shi, C. X., Zhu, Y. X., Palmer, S. E., et al. (2009). Identification of a potent natural triterpenoid inhibitor of proteosome chymotrypsin-like activity and NF-kappaB with antimyeloma activity in vitro and in vivo. Blood 113, 4027-4037. doi: 10.1182/blood-2008-09-179796

Tu, Y., Tan, F., Zhou, J., and Pan, J. (2018). Pristimerin targeting NF- $\kappa$ B pathway inhibits proliferation, migration, and invasion in esophageal squamous cell carcinoma cells. Cell Biochem. Funct. 36, 228-240. doi: 10.1002/cbf.3335

Valastyan, S., and Weinberg, R. A. (2011). Tumor metastasis: molecular insights and evolving paradigms. Cell 147, 275-292. doi: 10.1016/j.cell.2011.09.024

Wang, H., Shan, X. B., and Qiao, Y. J. (2017). PDK2 promotes chondrogenic differentiation of mesenchymal stem cells by upregulation of Sox6 and activation of JNK/MAPK/ERK pathway. Braz. J. Med. Biol. Res. 50, e5988. doi: 10.1590/1414-431x20165988

Wang, K., and Zhu, Y. (2018). Dexmedetomidine protects against oxygen-glucose deprivation/reoxygenation injury-induced apoptosis via the p38 MAPK/ERK signalling pathway. J. Int. Med. Res. 46, 675-686. doi: 10.1177/0300060517734460

Wang, Y., and Feigon, J. (2017). Structural biology of telomerase and its interaction at telomeres. Curr. Opin. Struct. Biol. 47, 77-87. doi: 10.1016/j.sbi.2017.06.010

Wang, Y., Zhou, Y., Zhou, H., Jia, G., Liu, J., Han, B., et al. (2012). Pristimerin causes G1 arrest, induces apoptosis, and enhances the chemosensitivity to gemcitabine in pancreatic cancer cells. PLoS One 7, e43826. doi: 10.1371/ journal.pone.0043826

Wei, W., Wu, S., Wang, X., Sun, C. K., Yang, X., Yan, X., et al. (2014). Novel celastrol derivatives inhibit the growth of hepatocellular carcinoma patient-derived xenografts. Oncotarget 5, 5819-5831. doi: 10.18632/oncotarget.2171

Wu, H., Li, L., Ai, Z., Yin, J., and Chen, L. (2019). Pristimerin induces apoptosis of oral squamous cell carcinoma cells via G1 phase arrest and MAPK/Erk1/2 and Akt signaling inhibition. Oncol. Lett. 17, 3017-3025. doi: 10.3892/ol.2019.9903

Wu, Q., Yang, Z., Nie, Y., Shi, Y., and Fan, D. (2014). Multi-drug resistance in cancer chemotherapeutics: mechanisms and lab approaches. Cancer Lett. 347, 159-166. doi: 10.1016/j.canlet.2014.03.013

Wu, T., Geng, J., Guo, W., Gao, J., and Zhu, X. (2017). Asiatic acid inhibits lung cancer cell growth in vitro and in vivo by destroying mitochondria. Acta Pharm. Sin. B 7, 65-72. doi: 10.1016/j.apsb.2016.04.003

Xia, Y., Shen, S., and Verma, I. M. (2014). NF-kappaB, an active player in human cancers. Cancer Immunol. Res. 2, 823-830. doi: 10.1158/2326-6066.CIR-14-0112

Xiao, J., Xing, F., Liu, Y., Lv, Y., Wang, X., Ling, M. T., et al. (2018). Garlic-derived compound S-allylmercaptocysteine inhibits hepatocarcinogenesis through targeting LRP6/Wnt pathway. Acta Pharm. Sin. B 8, 575-586. doi: 10.1016/j. apsb.2017.10.003

Xie, G. E., Yu, X., Liang, H., Chen, J., Tang, X., Wu, S., et al. (2016). Pristimerin overcomes adriamycin resistance in breast cancer cells through suppressing Akt signaling. Oncol. Lett. 11, 3111-3116. doi: 10.3892/ol.2016.4335

Yan, Y.-Y., Wang, F., Zhao, X.-Q., Wang, X.-K., Chen, Y.-F., Liu, H., et al. (2017). Degradation of P-glycoprotein by pristimerin contributes to overcoming ABCB1-mediated chemotherapeutic drug resistance in vitro. Oncol. Rep. 37, 31-40. doi: 10.3892/or.2016.5230

Yan, Y. Y., Bai, J. P., Xie, Y., Yu, J. Z., and Ma, C. G. (2013). The triterpenoid pristimerin induces U87 glioma cell apoptosis through reactive oxygen species-mediated mitochondrial dysfunction. Oncol. Lett. 5, 242-248. doi: $10.3892 / \mathrm{ol} .2012 .982$
Yang, H., Landis-Piwowar, K. R., Lu, D., Yuan, P., Li, L., Reddy, G. P., et al. (2010). Pristimerin induces apoptosis by targeting the proteasome in prostate cancer cells. J. Cell. Biochem. 103, 234-244. doi: 10.1002/jcb.21399

Yousef, B. A., Guerram, M., Hassan, H. M., Hamdi, A. M., Zhang, L.-Y., and Jiang, Z.-Z. (2016a). Pristimerin demonstrates anticancer potential in colorectal cancer cells by inducing G1 phase arrest and apoptosis and suppressing various pro-survival signaling proteins. Oncol. Rep. 35, 1091-1100. doi: 10.3892/ or.2015.4457

Yousef, B. A., Hassan, H. M., Guerram, M., Hamdi, A. M., Wang, B., Zhang, L.-Y., et al. (2016b). Pristimerin inhibits proliferation, migration and invasion, and induces apoptosis in HCT-116 colorectal cancer cells. Biomed. Pharmacother. 79, 112-119. doi: 10.1016/j.biopha.2016.02.003

Yousef, B. A., Hassan, H. M., Zhang, L.-Y., and Jiang, Z.-Z. (2018). Pristimerin exhibits in vitro and in vivo anticancer activities through inhibition of nuclear factor-кB signaling pathway in colorectal cancer cells. Phytomedicine 40, 140 147. doi: 10.1016/j.phymed.2018.01.008

Yousef, B. A., Hassan, H. M., Zhang, L. Y., and Jiang, Z. Z. (2017). Anticancer potential and molecular targets of pristimerin: a mini-review. Curr. Cancer Drug Targets 17, 100-108. doi: 10.2174/1568009616666160112105824

Zhang, J. Y., Lin, M. T., Tung, H. Y., Tang, S. L., Yi, T., Zhang, Y. Z., et al. (2016). Bruceine D induces apoptosis in human chronic myeloid leukemia K562 cells via mitochondrial pathway. Am. J. Cancer Res. 6, 819.

Zhang, J. Y., Lin, M. T., Zhou, M. J., Yi, T., Tang, Y. N., Tang, S. L., et al. (2015). Combinational treatment of curcumin and quercetin against gastric cancer MGC-803 cells in vitro. Molecules 20, 11524-11534. doi: 10.3390/ molecules200611524

Zhang, Y., Wang, J., Hui, B., Sun, W., Li, B., Shi, F., et al. (2019). Pristimerin enhances the effect of cisplatin by inhibiting the miR23a/Akt/GSK3beta signaling pathway and suppressing autophagy in lung cancer cells. Int. J. Molec. Med. 43, 1382-1394. doi: 10.3892/ijmm.2019.4057

Zhao, H., Wang, C., Lu, B., Zhou, Z., Jin, Y., Wang, Z., et al. (2016). Pristimerin triggers AIF-dependent programmed necrosis in glioma cells via activation of JNK. Cancer Lett. 374, 136-148. doi: 10.1016/j.canlet.2016.01.055

Zuo, J., Guo, Y., Peng, X., Tang, Y., Zhang, X., He, P., et al. (2015). Inhibitory action of pristimerin on hypoxia-mediated metastasis involves stem cell characteristics and EMT in PC-3 prostate cancer cells. Oncol. Rep. 33, 13881394. doi: $10.3892 /$ or.2015.3708

Conflict of Interest Statement: HS was employed by Infinitus (China) Company Ltd.

The remaining authors declare that the research was conducted in the absence of any commercial or financial relationships that could be construed as a potential conflict of interest.

Copyright (C) $2019 \mathrm{Li}$, Yan, Sun, Liu, Su, Chen and Zhang. This is an open-access article distributed under the terms of the Creative Commons Attribution License (CC BY). The use, distribution or reproduction in other forums is permitted, provided the original author(s) and the copyright owner(s) are credited and that the original publication in this journal is cited, in accordance with accepted academic practice. No use, distribution or reproduction is permitted which does not comply with these terms. 